\title{
MENYIAPKAN MASA DEPAN DI MASA DINI
}

\author{
Grace Putlia' ${ }^{1}$, Hary S. Sundoro ${ }^{2}$, Brendi Wijaya ${ }^{3}$, Ali Wardhana ${ }^{4}, J^{\prime}$ ny Rowena ${ }^{5}$ Budi $^{6}$, \\ Samuel $^{7}$, Pipiyen ${ }^{8}$ \\ 1,2,3,4,5,6,7,8 Program Studi Manajemen, Universitas Bunda Mulia
}

Diterima 16 Juli 2019 / Disetujui 19 Agustus 2019

\begin{abstract}
Knowing that human resources are important for the progress of a nation, it is necessary to have early preparation in order to be able to foster the future well. Supported also by the third Tri Dharma of Higher Education - Pengabdian Kepada Masyarakat (PKM), which states that the responsibilities of a teacher include transferring, transforming, and applying knowledge from within the campus to the public. Based on this, the University of Bunda Mulia conducted PKM activities by raising the topic "Preparing the Future in the Early Age". The selection of the subject of this research that has been adjusted to the topic is the Bhakti Utama School students. The method used in this PKM is ice breaking, the delivery of material includes lectures, sharing experiences and video playback as well as a question and answer session that results in two-way communication. In short, the material presented is in the form of the importance of money management and preparation for further education, planning provides direction and reduces uncertainty, and how to change bad behavior and habits. Each session is thirty minutes long. This PKM activity is expected to be held again, of course with more varied topics.
\end{abstract}

Keywords: early childhood, future, education, PKM.

\begin{abstract}
ABSTRAK
Mengetahui bahwa sumber daya manusia penting bagi kemajuan suatu bangsa, maka perlu adanya persiapan dini untuk dapat menyembut masa depan dengan baik. Ditunjang pula adanya Tri Dharma perguruan tinggi yang ketiga mengenai Pengabdian Kepada Masyarakat (PKM), yang menyebutkan bahwa tanggung jawab seorang pengajar termasuk mentransfer, mentransformasikan, dan mengaplikasikan ilmu pengetahuan dari dalam kampus kepada masyarakat. Berdasarkan hal itu Universitas Bunda Mulia melakukan kegiatan PKM dengan mengangkat topik "Menyiapkan Masa Depan di Masa Dini". Adapun pemilihan subjek penelitian ini yang telah disesuaikan dengan topik adalah peserta didik Sekolah Bhakti Utama. Metode yang digunakan dalam PKM ini adalah ice breaking, penyampaian materi meliputi ceramah, berbagi pengalaman dan pemutaran video serta adanya sesi tanya jawab yang menghasilkan komunikasi dua arah. Secara singkat, materi yang disampaikan berupa pentingnya pengelolaan uang dan persiapan menempuh jenjang pendidikan selanjutnya, perencanaan menyediakan arah dan mengurangi ketidakpastian, serta begaimana merubah perilaku dan kebiasaan buruk. Masing-masing sesi berdurasi tiga puluh menit. Kegiatan PKM ini diharapkan dapat terselenggara kembali, tentunya dengan topik yang lebih bervariasi.
\end{abstract}

Kata Kunci: masa dini, masa depan, pendidikan, PKM.

*Korespondensi Penulis:

E-mail: gputlia@ubm.ac.id 


\section{PENDAHULUAN}

\section{Latar Belakang}

Kemajuan suatu bangsa dapat digapai apabila pembentukan diri secara terusmenerus mengalami keberlanjutan meskipun banyak tantangan yang akan dihadapi. Mengatasi hal tersebut, kualitas sumber daya manusia kini menjadi kunci utama untuk meraih masa depan (Kompas, 2006). Das (2015) selanjutnya mengemukakan bahwa pentingnya peranan sumber daya manusia di dalam membentuk karakter atau kapabilitas seseorang di dalam bertindak dan berpikir dapat menentukan arah yang akan dituju oleh suatu bangsa. Hal ini karena tidak peduli seberapa banyak sumber daya alam (natural resources) yang dimiliki oleh suatu bangsa atau negara, namun apabila masyarakat atau sumber daya manusia (human resources) yang berada di negara tersebut tidak mampu memanfaatkannya secara efektif, efisien, serta optimal, maka sumber daya alam yang dimiliki oleh negara tersebut hanya akan terbuang sia-sia (Koesmono, 2001; Ras, 2015).

Koesmono (2001) selanjutnya memaparkan bahwa kualitas sumber daya manusia tidak berkaitan atau tidak berpengaruh terhadap jumlah sumber daya manusia yang ada di suatu negara. Artinya, jumlah SDM yang melimpah di suatu negara tidak dapat menjadi jaminan bahwa negara tersebut memiliki SDM dengan kualitas yang tinggi, dan sebaliknya. Alhasil, penting untuk dipahami oleh masyarakat luas bahwa pengembangan atau peningkatan mutu SDM dari suatu bangsa atau negara perlu dilakukan oleh seluruh negara, bai negara yang jumlah penduduknya sedikit, sedang, ataupun banyak.

Berkaitan dengan usaha peningkatan kualitas SDM ini, program pengembangan anak usia dini dapat menjadi langkah, program, atau strategi awal yang dapat diimplementasikan guna meningkatkan kualitas serta memeprsiapkan sumber daya manusia untuk generasi mendatang (Kompas, 2007). Ditunjang pula dengan Tri Dharma perguruan tinggi yang ketiga yaitu
Pengabdian Kepada Masyarakat (PKM), menyebutkan bahwa tanggung jawab seorang pengajar selain melakukan pengajaran dan penelitian adalah mentransfer, mentransformasikan, dan mengaplikasikan ilmu pengetahuan dari dalam kampus kepada masyarakat. Maka, pada kesempatan kali ini, Universitas Bunda Mulia melakukan kegiatan tersebut dengan topik "Menyiapkan Masa Depan di Masa Dini”. Adapun pemilihan subjek kegiatan ini adalah siswa/i didik Sekolah Bhakti Utama, dimana pemilihan subjek tersebut telah disesuaikan dengan topik PKM.

\section{Identifikasi Masalah}

Pada kegiatan PKM kali ini, sasaran peserta adalah siswa/i kelas 7, 8 dan 9 dari Sekolah Bhakti Utama yang tepatnya berlokasi di Jl. Krendang Sel. No. 18A Tambora, Jakarta 11260. Sebelumnya, penulis telah meninjau langsung lokasi sekolah yang ada juga bertatap muka dengan beberapa guru. Secara keseluruhan kondisi tampak baik, namun memang siswa/i sekolah tersebut membutuhkan asupan diluar materimateri pokok yang telah diberikan para guru setiap harinya, misalnya seperti hal-hal apa saja yang perlu dipikirkan dan dipersiapkan untuk masa depan mereka. Maka, hal inilah yang mendorong kegiatan PKM ditujukan kepada siswa/i Sekolah Bhakti Utama.

\section{Tujuan dan Manfaat Kegiatan}

Adapun tujuan dan manfaat diselenggarakannya kegiatan PKM ini adalah untuk:

a. Memberikan wawasan bagi peserta terkait investasi dan tingkat pendidikan.

b. Membantu peserta agar dapat merencanakan langkah ideal untuk mempersiapkan masa depan.

c. Membekali peserta mengenai kebiasaankebiasaan baik yang dapat diterapkan.

d. Membantu peserta menyiapkan diri memasuki jenjang selanjutnya yaitu perkuliahan dan kerja. 


\section{METODE PENELITIAN}

Pelaksanaan kegiatan PKM ini memadukan beberapa teknik. Diawali dengan menggugah semangat para peserta melalui ice breaking, sehingga seluruh peserta dapat turut aktif dalam kegiatan. Chlup \& Collins (2010) mengemukakan bahwa teknik atau metode ice breaker merupakan salah satu metode yang paling efektif di dalam meningkatkan daya juang atau semangat siswa/i di dalam mengikuti suatu kegiatan, terutama kegiatankegiatan yang berkaitan dengan aktivitas pembelajaran. Hal ini karena sering kali, sebelum dilaksanakannya sebuah aktivitas, siswa/i pada umumnya memiliki persepsi dasar bahwa kegiatan atau aktivitas pembelajaran yang akan diikuti merupakan kegiatan yang memberatkan, memakan waktu, membosankan, serta memiliki materi yang sulit untuk dipahami. Dengan demikian, metode ice breaker dapat secara efektif digunakan atau diimplementasikan untuk menghilangkan serta mengubah persepsi negative ini kedalam persepsi positif.

Yeganehpour (2016) selanjutnya menambahkan bahwa metode ice breaking ini memiliki tingkat efektivitas yang lebih tinggi apabila diaplikasikan ke siswa-siswi yang berada di tingkatan SD (elementary) hingga SMP (junior high school). Hal ini karena mengingat bahwa siswa/siswi yang berada atau duduk pada tingkatan itu memiliki kapabilitas pemikiran serta emosional yang masih belum stabil dan belum matang (mature) apabila dibandingkan dengan siswa/siswi yang berada di tingkatan diatasnya (SMA ke atas). Selain itu, metode ice breaking ini juga memiliki tingkat efektivitas yang tinggi di dalam meningkatkan kemampuan berbicara, berbahasa, serta berpikir seseorng apabila diimpelementasikan secara tepat (Varvel, 2002; Pillai, 2007; Yeganehpour, 2016).

Setelah melaksanakan atau melakukan metode ice breaking kepada para siswa/i, acara kemudian dilanjutkan pemberian materi dari para pembicara berupa ceramah, berbagi pengalaman yang ditunjang penggunaan media yang tepat untuk mendukung proses kegiatan (penggunaan layar LCD untuk menampilkan materi juga pemutaran video), serta pada setiap akhir sesi diberikan kesempatan bertanya agar terjadi komunikasi dua arah.

\section{HASIL DAN PEMBAHASAN}

$\begin{array}{ccc}\text { Kegiatan } & \text { PKM dengan peserta } \\ \text { siswa/i } & \text { Sekolah Bhakti Utama ini }\end{array}$ dilaksanakan pada Kamis, 18 April 2019. Kegiatan tersebut bertempat di Sekolah Bhakti Utama yang berlokasi di Jl. Krendang Sel. No. 18A Tambora, Jakarta 11260. Kegiatan dimulai pukul 12.25 WIB dan berakhir pukul 14.10 WIB. Para peserta berasal dari perwakilan kelas 7, kelas 8 dan kelas 9 yang secara keseluruhan total terdapat 19 orang. Seluruh peserta mengikuti setiap sesi kegiatan dengan baik.

Setelah ice breaking, sesi pertama dengan topik "Future = Financial + Education" disampaikan oleh dosen Program Studi Manajemen yakni Hary Saputra Sundoro, SE., ME dan Grace Putlia, SE., MM. Pentingnya pengelolaan uang yang pas sesuai kebutuhan masing-masing individu hingga cara menabung dan investasi turut disampaikan. Hill \& Donohoe (2019) mengemukakan bahwa keberhasilan seseorang di dalam mengelola sistem atau kondisi keuangan pribadi tidak bergantung dari seberapa banyak uang yang diperoleh (entah dari bekerja, usaha/bisnis, freelance activities, dan sebagainya), namun tergantung dari 2 hal, yaitu seberapa banyak uang yang kita habiskan, serta kemampuan kita di dalam menyeimbangkan pendapatan dan pengeluaran terhadap uang simpanan yang kita miliki. Harms (2019) selanjutnya menambahkan bahwa meskipun mudah untuk dikatakan dan dikemukakan, mengelola sistem keuangan adlaah salah satu hal yang paling sulit dilakukan oleh seseorang sepanjang hidupnya. Hal ini karena meskipun kita telah banyak mendengar masukanmasukan yang berkaitan dengan bagaimana cara mengelola keuangan dengan baik, namun hasrat alamiah manusia untuk membeli produk/jasa yang diinginkan tidak dapat dipungkiri lagi, meskipun mungkin sebenarnya produk/jasa yang dibeli bukanlah sesuatu yang urgent dibutuhkan oleh orang tersebut. Dengan demikian, maka penting bagi kita (terutama yang masih tergolong anaanak atau remaja) untuk dapat memahami 
bahwa di dalam mengelola sistem keuangan pribadi kita, yang perlu kita lakukan adalah dengan mengurangi hasrat kita di dalam membeli sesuatu yang sebenarnya tidak terlalu kita butuhkan (Harms, 2019).

Moulden (2014) serta Harms (2019) mengemukakan bahwa terdapat beberapa alasan mengapa penting bagi setiap manusia atau individu di dalam mengelola keuangannya dengan baik, diantaranya adalah sebagai berikut:

\section{a. Get Out of Debt}

Moulden (2014) serta Harms (2019) mengemukakan bahwa salah satu permasalahan yang muncul di kalangan masyarakat luas di zaman saat ini adalah hutang (debt), dimana, banyak masyarakat yang mengeluh mengenai betapa banyaknya hutang yang mereka miliki, serta tingkat kebutuhan akan pekerjaan baru yang menjanjikan atau dapat memberikan tingkat gaji (salary level) yang lebih tinggi. Namun, menurut Moulden (2014) dan Harms (2019), tingkat gaji, pendapatan, ataupun pemasukkan yang kita peroleh setiap periodenya tidak akan menjamin bahwa seseorang akan terbebas dari lilitan hutang. Namun, justru kemampuan seseorang di dalam mengatur offset atau gap antara uang yang diterima dengan uang yang dikeluarkan-lah yang akan menentukan tingkat hutang yang dimilikii oleh seseorang.

Dengan demikian, maka dapat dipahami bahwa tidak peduli seberapa besar uang yang kita terima setiap hari, bulan, atau tahunnya, namun apabila kita masih belum bisa mengatur keuangan pribadi kita dengan baik, dimana kita masih mengeluarkan uang dengan jumlah yang lebih besar dibandingkan dengan pendapatan yang kita peroleh, maka hutang tidak akan pernah jauh dari kita. Namun, apabila kita mampu menahan diri untuk tidak membeli barang-barang yang sebenarnya tidak kita butuhkan, atau juga apabila kita mampu di dalam menggunakan prinsip Our Expenses or Expenditures should always be greater than our Income or Revenue (Tingkat pengeluaran kita haruslah selalu lebih rendah dibandingkan dengan tingkat pendapatan kita), maka kita akan jauh dari hutang (debt).

\section{b. Expect the Unexpected}

Hill \& Donohoe (2019), Moulden (2014) serta Harms (2019) selanjutnya mengemukakan bahwa salah satu keuntungan yang dapat diraih atau dinikmati dari baiknya tingkat kemampuan kita di dalam mengelola pendapatan atau uang yang kita miliki adalah bahwa kita akan jauh lebih siap di dalam menghadapi segala jenis gangguan, disrupsi (disruption), serta hal-hal yang tak terduga yang mungkin dapat memberikan dampak bagi keuangan yang kita miliki. Sebagai contoh, sudden unemployment, economic turmoil, serta kejadian-kejadian tak terduga lainnya (sakit, keperluan transportasi untuk mengunjungi sanak saudara yang menikah, sakit, dsb) adalah beberapa contoh ilustrasi yang dapat menjelaskan kejadian-kejadian tak terduga (unexpected \& unplanned) yang dapat menguras tabungan atau simpanan uang yang kita miliki.

Apabila kita memiliki kemampuan pengaturan keuangan atau simpanan yang buruk, dimana kita dapat mengelola keuangan kita dengan baik, maka bukan tak mungkin kejadian-kejadian tak terduga (seperti yang telah diilustrasikan di atas) dapat menguras habis sisa tabungan kita, yang dimana mungkin kita tidak menyangka bahwa hal itu akan terjadi. Dengan demikian, selain agar kita terbebas atau terlepas dari hutang, kemampuan kita di dalam mengelola keuangan, simpanan, pengeluaran, serta investasi dapat memperkuat persiapan atau kesigapan kita di dalam menghadapi kejadian-kejadian tak terduga seperti yang dikemukakan di atas.

\section{c. Peace of Mind \& Body}

Hill \& Donohoe (2019), Moulden (2014) serta Harms (2019) selanjutnya mengemukakan bahwa keuntungan lainnya yang dapat diperoleh dari memiliki kemampuan pengelolaan dana yang baik adalah bahwa kita dapat mencapai kedamaian jiwa dan raga dengan baik. Berkaitan dengan hal ini, Harms (2019) mengemukakan bahwa seringkali manusia didera perasaan stress atau tertekan akibat hal-hal yang muncul di periode waktu tertentu, misalkan tagihan listrik, tagihan air, tagihan uang sekolah, bayar gaji karyawan, serta hal-hal lainnya yang seringkali menyebabkan perasaan tertekan akibat dari berpengaruhnya hal-hal 
tersebut pada kondisi finansial kita (financial stress). Dengan demikian, maka dapat dipahami bahwa kemampuan kita di dalam mengelola keuangan kita dengan baik dapat menentukan bagaimana kesiapan serta kesigapan kita di dalam mengatasi financial stress (tekanan finansial) kibat adanya hal-hal tersebut.

\section{d. Achieving Goals}

Hill \& Donohoe (2019), Moulden (2014) serta Harms (2019) mengemukakan bahwa keuntungan lain dari memiliki kemampuan pengelolaan dana yang baik adalah bahwa hal tersebut akan membantu kita di dalam menggapai impian atau cita-cita yang kita inginkan. Harms (2019) menambahkan bahwa kemampuan pengelolaan dana yang baik haruslah dapat dimiliki oleh setiap orang, mengingat bahwa kemampuan kita di dalam menabung, mengelola, serta menginvestasikan sebagian dari uang tersebut adalah bekal berharga di masa mendatang guna membantu kita mencapai tujuan yang kita inginkan. Namun, apabila kita gagal mengelola keuangan kita dengan baik, maka akan sulit bagi kita untuk mencapai impian tersebut.

Misalkan, sebagai contoh, "A" ingin berinvestasi dengan membeli obligasi setiap bulannya. Namun, karena "A" memiliki manajemen keuangan pribadi yang buruk, maka ia tidak lagi memiliki dana yang cukup untuk berinvestasi untuk membeli obligasi tersebut. Dengan demikian, maka penting bagi kita untuk dapat mengatur keuangan kita dengan baik, dimana, nantinya apabila kita ingin melakukan sesuatu guna mencapai tujuan (goals) yang kita ingin capai, kita dapat melaksanakannya dengan baik.

Setelah itu, dalam sesi ini, diberikan pula contoh perhitungan sederhana sisa uang saku harian yang rutin dapat ditabung ternyata berbuah nominal yang tidak sedikit, menjadi daya tarik tersendiri bagi peserta. Dilanjutkan materi persiapan menempuh jenjang pendidikan selanjutnya yang lebih tinggi juga gambaran umum mengenai pekerjaan yang dapat digapai. Sesi pertama ditutup dengan diputarnya video singkat mengenai masih banyaknya anak-anak di luar sana yang mengenyam pendidikan dengan sarana prasarana seadanya, diharapkan dapat menggugah rasa bersyukur peserta dan membangkitkan kerajinan mereka dalam bersekolah.

\section{Versi Online: http://journal.ubm.ac.id/ Hasil Penelitian}

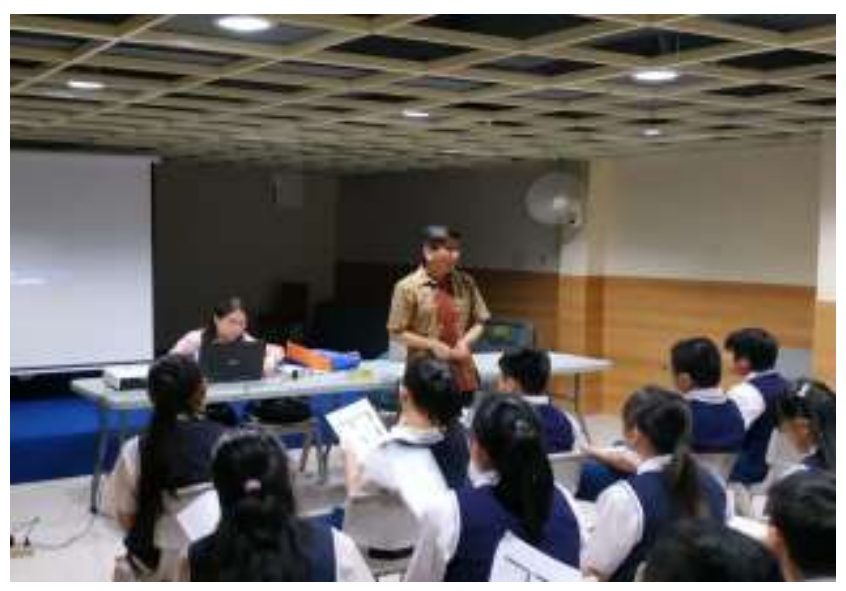

Gambar 1. Sesi 1 oleh: Hary S. Sundoro, SE., ME dan Grace Putlia, SE., MM Sumber: Peneliti, 2019

Sesi kedua adalah penyampaian materi oleh dosen Program Studi Manajemen yakni Ali Wardhana SE., MBA dan Brendi Wijaya, SE., MM dengan topik "Plan Your Future". Dikemukakan betapa pentingnya perencanaan untuk menuju masa depan. Seseorang harus memiliki tujuan, ketika tujuan itu telah ada maka akan lebih mudah dalam menentukan langkah tepat menuju tujuan (cita-cita) tersebut. Dikatakan bahwa, "A goal without a plan is just a wish" -perencanaan menyediakan arah dan mengurangi ketidakpastian. Ada metode yang diterapkan menuju hal itu yang disebut dengan metode SMART: (S)pecific, (M)easurable, (A)chievable, (R)ealistic, (T)imely. S(pecific) dapat diartikan sebagai sebuah konsep yang mengajarkan kepada kita semua, khususnya mereka yang berasal dari kalangan muda, untuk dapat menentukan goal nya se-spesifik mungkin, dengan harapan bahwa goal atau tujuan itu nantinya akan dapat dengan mudah tercapai dengan perencanaan yang telah kita buat.

Berikutnya, (M)easurable, dapat dipahami sebagai sebuah metode dimana kita harus dapat menentukan tujuan yang ingin kita capai, dimana, tujuan itu haruslah masuk 
akal, dapat diukur, serta secara realistis memang dapat kita capai sesuai dengan kemampuan kita. Selain itu, ada juga konsep (A)chievable, dimana, mirip dengan konsep sebelumnya, mengkomunikasikan kepada kita bahwa target yang ingin kita capai haruslah berada di dalam jangkauan kita, sehingga, meningkatkan probabilitas kita untuk dapat mencapai dan merealisasikan tujuan tersebut.

Dua konsep berikutnya adalah (R)ealistic dan (T)imely, dimana, setiap tujuan atau goal yang ingin kita tentukan haruslah realistis (dalam artian tidak mengada-ada dan memang masuk akal dan dapat dicapai). Selain itu, kita harus yakin dan realistis bahwa setiap goal atau tujuan yang kita ingin capai dapat terselesaikan atau terrealisasi dapat timeframe yang telah kita tentukan. Terakhir,

Sesi terakhir, yaitu sesi ketiga penyampaian materi dengan topik "Your Habit Determine Your Future" oleh Janny Rowena, SE., MM dan Budi, S.Kom., MM. Diawali dengan cerita pengalaman pribadi yang kebanyakan orang juga pasti kerap kali mengalaminya mengenai kurangnya manajemen waktu yaitu terlambat berangkat sekolah menjadi pembuka yang membuat geli peserta. Sehingga di sesi terakhir ini, semangat peserta dapat tetap terkontrol.

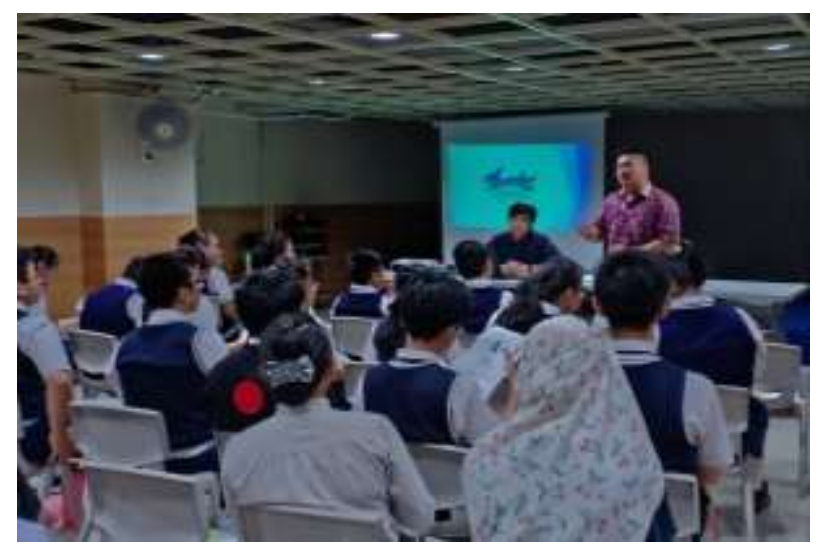

Gambar 2. Sesi 2 oleh: Ali Wardhana SE., MBA dan Brendi Wijaya, SE., MM Sumber: Peneliti, 2019

\footnotetext{
Disampaikan bahwa betapa pentingnya mengubah perilaku dan kebiasaan-kebiasaan buruk yang tampaknya kecil atau sepele namun jika itu berkelanjutan akan membawa dampak buruk yang cukup
}

besar di kemudian hari. Mulai dari cara bertutur kata, berjalan, duduk, makan, menatap orang lain hingga komunikasi semuanya wajib diperhatikan dan tentunya hal-hal tersebut penting untuk mempersiapkan mereka yang nantinya akan menempuh dunia kerja dan menjadi penerus bangsa. Hal in pun sejalan dengan hasil penelitian yang dilakukan oleh Ras (2015) dan Yeganehpour (2016), yang mengemukakan bahwa atribut, sikap, serta seluruh kemampuan interpersonal (interpersonal skills) yang dimiliki oleh seseorang dapat menentukan keberhasilan suatu bangsa atau negara di masa mendatang. Merancang masa depan anak sejak dini merupakan aspek terpenting yang perlu dikatahui oleh anak-anak sejak dini dimana aspek tersebut sangat mempengaruhi masa depan anak tersebut. Selain itu pendidikan merupakan salah satu hal yang dapat menjadi tolak ukur anak tersebut baik ketika dalam bermasyarakat maupun dalam dunia pendidikan.

Pendidikan sejak dini sangat penting untuk disosialisasikan karena hal tersebut dapat membantu untuk menghadapi dan mempersiapkan masa depannya kelak.

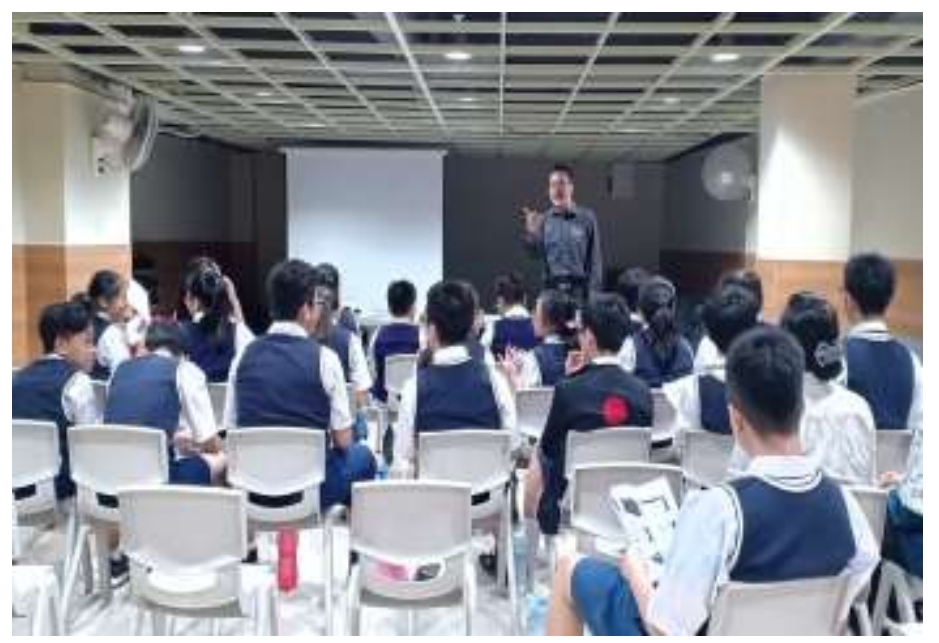

$$
\begin{gathered}
\text { Gambar 3. Sesi } 3 \text { oleh: Janny Rowena, SE., MM dan } \\
\text { Budi, S.Kom., MM. } \\
\text { Sumber: Peneliti, } 2019
\end{gathered}
$$

Pendidikan merupakan salah satu sarana anak untuk menuju kesuksesan, peran dari orang 
tua pun sangatlah penting untuk membuat anak tersebut paham dan sadar dengan dunia pendidikan selain itu pendidikan juga dapat membantu anak-anak ketika sudah ada di masyarakat dimana ditengah masyarakat anak-anak dapat membedakan pergaulan yang baik dan buruk. Peran dunia pendidikan juga sangat membantu dalam menyeimbangkan kehidupan bermasyarakat dan dalam masa depan yang lebih baik. Informasi mengenai Pendidikan yang akan diambil jenjang pendidikan yang di tempuh dan jurusan yang dipilih juga sangat membantu dalam sosialisasi ini. Jurusan dan pendidikan yang tepat sangat membantun anak-anak dalam dunia pendidikan, sehingga anak-anak mempunyai gambaran yang jelas seperti apa dunia pendidikan itu dan juga menyadari betapa pentingnya dunia pendidikan dan perlunya hal tersebut sejak dini.

Seiring berjalan nya waktu dan bertambahnya pendidikan tentu dapat mengubah perilaku dan sikap dari anak jika hal tersebut dapat disosialisasikan sejak dini maka dapat mengubah persepsi dan pandangan mereka tentang pendidikan. Selain itu perilaku dan kebiasaan buruk pun dapat diubah dengan adanya pendidikan yang lebih baik, Komunikasi merupakan salah satu cara yang dapat kita salurkan kepada anak-anak jika pendidikan dapat tersalurkan dengan baik maka komunikasi dan perilaku anak-anak dapat berubah seiring dengan berjalannya waktu. Oleh karena itu pentingnya sosialisasai ini adalah untuk menambah wawasan anak sejak dini bahwa dengan adanya pendidikan yang baik maka selain dari masa depan, perilaku, dan komunikasi pun dapat berubah dengan lebih baik lagi.

\section{SIMPULAN}

Kegiatan PKM dengan topik "Menyiapkan Masa Depan di Masa Dini" secara keseluruhan terlaksana dengan baik dan lancar melihat antusiasme peserta dari awal hingga akhir berikut dengan olah data umpan balik yang diterima. Walaupun adanya keterbatasan waktu, namun keseluruhan materi dapat tersampaikan. Besar harapan kegiatan serupa dapat kembali terselenggara yang mana dapat melibatkan peserta didik Sekolah Bhakti Utama dengan topik yang lebih variasi. Selain itu, penulis juga memiliki harapan besar bahwa kegiatan PKM ini dapat memberikan manfaat, pencerahan, serta pengetahuan kepada para siswa/i Sekolah Bhakti Utama, dimana penulis berharap agar siswa/i Sekolah Bhakti Utama dapat menjadi individu-individu dengan kemampuan pengelolaan uang yang baik, memiliki kemampuan perencanaan karir dan masa depan yang baik, serta mampu mengadaptasi kebiasaan atau habit yang baik, agar mereka dapat menjadi pribadi yang positif, berpendidikan, berprestasi, serta memiliki masa depan yang cerah

\section{DAFTAR PUSTAKA}

Chlup, D.T., \& Collins, T.E. (2010). Breaking the Ice: Using Ice-breakers and Re-energizers with Adult Learners, American for Adult and Continuing Education, Vol. 21 (3-4), pp. 34-39.

Dover, K. H. (2004). Break the ice in classrooms and meetings. Icebreakers. Retrieved May 24, 2015 from http://adulted.about.com/cs/icebreakers /a/icebreaker.htm

Harms, L. (2019). The Importance of Good Money Management, retrieved from: https://budgeting.thenest.com/importan ce-good-money-management3392.html

Hill, B. \& Donohoe, A. (2019). Importance of Money Management, retrieved from: https://budgeting.thenest.com/importan ce-money-management-3204.html

Koesmono, T. (2001). Pengaruh Faktor Pengembangan Sumber Daya Manusia Terhadap Produktivitas Tenaga Kerja Produksi Pada Pt Siwi, Ekuitas, Vol. 5 (4), pp. 389-409.

Kompas. (2006). Pendidikan TK: Pembelajaran tematik solusi bagi kelas awal.

Kompas. (2007). Tingkatkan investasi pada pengembangan anak usia dini.

Kompasiana. (2019). Merencanakan Pendidikan Anak Sejak Dini; 
Menyiapkan Kenyamanan Hidup di

Masa Depan from:

https://www.kompasiana.com/hadi.sant

oso/5631e319f97a61cc0715415b/mere

ncanakan-pendidikan-anak-sejak-dini-

menyiapkan-kenyamanan-hidup-di-

$\underline{\text { masa-depan?page }=\text { all }}$

Moulden, K. (2014). 10 reasons why managing your money effectively is important, retrieved from: https://www.slideshare.net/KieranMoul den/10-reasons-39141333

Pillai, M. (2007). Classroom icebreaker activities for students. Retrieved May 24, 2015 from http://www.buzzle.com/articles/classro om-icebreaker-activities-forstudents.html.

Ras, D. (2015). The Importance of Human Resource Management, retrieved from: http://morungexpress.com/importanceof-human-resource-development/

Varvel, E.V. (2002). Ice-breakers. Retrieved May 24, 2015 from http://www.ion.illions.edu/resources/po intersclickers/2002_01/index.asp.

Yeganehpour, P. (2016). The Effect Of Using Different Kinds Of Ice- Breakers On Upper-Intermediate Language Learners' Speaking Ability, Ines Journal, Vol. 3 (6), pp.217-238 